\title{
From charity to 'not-for-profit': changes in the role and structure of voluntary social service agencies
}

Jo Barnes

\begin{abstract}
Justice is not about measurable outcomes, justice is about opportunity, justice is about access, justice is about getting your right to a whole lot of basic life things. (Faith-based agency director)
\end{abstract}

From 1984 to 1999 , New Zealand underwent 15 years of significant welfare reform and welfare state restructuring. In the US, President Clinton took office in 1993 declaring his commitment 'to end welfare as we know it' and in 1996 signed into law the Personal Responsibility and Work Opportunity Reconciliation Act (see Chapter Six of this book). This Act dramatically changed the welfare system. In the wake of these reforms, this chapter discusses changes regarding welfare governance as they relate to the role of the third sector or voluntary social service agencies. The chapter presents the results of a study into the organisational changes of non-government social provision agencies as they move from being charities to 'not-for-profit businesses' as state support for welfare declines in New Zealand and the US.

This chapter discusses findings from a study undertaken in 2001-02 on not-for-profit social service organisations in the regional city of Hamilton, a city of 166,000 people, in the context of changes in New Zealand welfare governance from 1984 to 1999 and inTampa, Florida, a city of just over 300,000 people, following the US welfare reforms of the Clinton administration.

It is argued that the move from being charities to 'not-for-profit businesses' affected both the way that agencies were structurally 
organised in terms of their management and the types of clients that they were able to help. It is argued that because of the fiscal and procedural accountability that was demanded of them, the agencies made deliberate decisions to become 'managerialise in their way of working and at the same time, albeit unconsciously, initiated a new concept of the deserving and undeserving.

The chapter is structured as follows. It starts with a description of the changes that occurred as New Zealand moved from a welfare state based on Keynesian philosophy to a market-led user-pays economy and the effects of the Clinton administration's welfare reform. Next, an overview is given of the research undertaken in Hamilton, New Zealand, and Tampa, Florida, US, of not-for-profit social service agencies. Then it focuses on the changes that have occurred in the structure and philosophies of these agencies and their move to managerialism and professionalisation. The chapter then discusses the re-emergence of the concept of the 'deserving poor' and argues that the requirement to demonstrate 'successful' programmes has resulted in a need to target those clients who are willing and able to change their behaviour in a particular way.

\section{The change in governance from 'Keynesian welfare' to the 'free market'}

The transformation of the public sector in many western industrialised countries has been mirrored in New Zealand. Indeed, writing in 1998, John Gray argues that The neo-liberal experiment in New Zealand is the most ambitious attempt at constructing the free market as a social institution to be implemented anywhere this century' (Gray, 1998, p 39). Larner and Craig (2002, pp 8-10) describe the three phases of 'New Zealand's restructuring project'. The first stage saw a return to power of a Labour government, which, when faced with a deepening financial decline, abandoned New Zealand's Keynesian managed economy in favour of a pure neo-liberal model of lean government and a free-market economy. From 1984, the Labour Party implemented policies of deregulation that involved abolishing controls on prices, wages and interest rates, removing export subsidies and reducing tariffs. Many state-owned enterprises and assets were privatised and the principle of full employment was replaced by a monetarist goal of price stability (Gray, 1998). Despite a doctrine of 'rolling back the state' economically, the Labour government attempted to preserve its socially liberal policies on education, healthcare and Maori affairs. However, following the 1987 
election such 'social policies were made more compatible with its [the government's] economic reforms and these were also shifting further in the direction of market liberalism' (Cheyne et al, 2005, p 39).

The second phase in the early 1990s under a conservative National government continued and extended the market reform process and additionally reformed the welfare state in a major way. 'The reforms were aimed at reducing dependency on the state, instituting a more modest safety net, and eliminating the vestiges of universal access to welfare' (Cheyne et al, 2005, p 39). The government's core business was seen as making policy and funding essential services; service delivery was to be transferred to the private market and the community. Public hospitals became commercial enterprises required to compete with private medical providers, delivery of education became the responsibility of local school boards and entitlement to welfare benefits was severely reduced. The State Housing body, which provided public housing, underwent a number of structural and name changes. Also, in 1993 housing rentals were calculated according to market values, rather than the cap of $25 \%$ of income, which had previously allowed low-income families access to decent housing. The balance between targeted and universal benefits, which had in the late post-war period ensured that everyone benefited from the welfare state in some way, now tipped towards further targeting. For example, entitlement to the nontaxable universal family benefit was combined with family assistance and means tested. Community Services Cards were introduced for low-income families and only those families were entitled to a number of health subsidies that had previously been universally available (St John, 1994). 'In less than a decade, New Zealand had gone from a bastion of welfare interventionism to a neo-liberal's paradise' (Kelsey, 1995, p 297).

The third phase, according to Larner and Craig (2002, p 9) is one in which 'local partnerships have come to the centre stage politically'. With the return of a Labour government in 1999 this phase of governance is characterised by a distancing from the market and individualised approaches of the 1980s and 1990s neo-liberalism and a 'joining up' of levels of government with the community and 'formalising of these relationships around shared values and place based goals ... a broad project in which every organisation ought to be involved, and which will benefit all' (Larner and Craig, 2002, p 9). In its 2005 Statement of Intent, the New Zealand Ministry of Social Development emphasised this viewpoint: 
The priorities and strategies outlined recognise that successful social development involves: ... government working in partnership with local authorities, with the community and voluntary sector, and with the private sector to develop 'joined up' local services. (MSD, 2005, p 9)

Since Labour came to power in 1999, a number of reforms have taken place in terms of welfare protection. Nevertheless, the emphasis on partnership does not diminish the increased role that non-governmental organisations had undertaken during the previous years.

\section{The US and PRWORA}

Welfare in the US does not mirror that of New Zealand. 'In the United States welfare has always meant one thing: means-tested assistance paid primarily to lone mothers and their children' (Deacon, 2002, p 5). In 1996, President Clinton signed into legislation the Personal Responsibility and Work Opportunity Reconciliation Act (PRWORA).This Act signalled major changes to the US welfare system. 'At the heart of these changes was the abolition of the right to welfare' (Deacon, 2002, p 91).The basis of the PRWORA was to move the existing welfare system 'into one that requires work in exchange for time-limited assistance' (US Department of Health and Human Services, 1996, p 1). In the preamble of the PRWORA the goals of the legislation were:

to provide assistance to needy families so that children may be cared for in their own homes or in the homes of relatives; to end the dependence of needy parents on government benefits by promoting job preparation, work, and marriage; to prevent and reduce the incidence of out-of-wedlock pregnancies and establish annual numerical goals for preventing and reducing the incidence of these pregnancies; and to encourage the formation and maintenance of two-parent families. (PRWORA, 1996)

Until the implementation of PRWORA cash assistance had been paid to single mothers under the Aid to Families with Dependent Children (AFDC) Programme. Although each state was required 
by law to pay AFDC to those whose income fell below certain limits, the level of payment was left to those individual states. The PRWORA abolished AFDC and replaced it with the Temporary Assistance for Needy Families (TANF) Programme and thus lifted the states' obligation to pay cash assistance. As Deacon notes, 'The relevant part of the Act began with a declaration that it should not "be interpreted to entitle any individual or family to assistance under any state program funded under this part"' (Deacon, 2002, p 91; see also Weaver, 2000, p 456). There is no doubt that the changes made to the US welfare system in the 1990s had a significant impact. While the reforms were successful in diverting people from public assistance and the combination of a strong economy and intensive welfare-to-work policies reduced caseloads, the general consensus was that the policies were substantially less effective in helping families move out of poverty (Acker et al, 2002). The demand on the non-governmental agencies continued to increase as they struggled to cover the unmet needs of families throughout the US.

\section{The research}

Field research was undertaken in 2001-02. The objective of that research was to identify the organisational changes within nongovernmental social provision agencies that had taken place during the neo-liberal era of the successive Labour and National Governments of the 1990s in New Zealand and during the Clinton era in the US. These organisational changes not only involved a philosophical upheaval as non-governmental agencies moved from being 'charities' to 'not-for-profit businesses', but the changes also resulted in a new view of the services that the agencies could provide.

Representatives of seven community social service agencies in Hamilton, New Zealand, and two in Tampa, Florida, US, took part in interviews. All of the agencies were 'faith-based' organisations. Although their programmes are similar to other community programmes, these may be shaped by significant differences in what the social service means to the staff and volunteers (see Hartford Institute for Religion Research, 2000). The agencies involved in this research offered a number of different services. Eight of the nine provided accommodation serving various groups - families, women and children, ex-prisoners, people with mental health problems, night shelters, and so on. All of them provided some type of counselling services, six provided food delivery services 
(foodbank or feeding sites) and five of them ran opportunity shops selling used clothing, furniture and the like.

Interviews of one to two hours' duration were conducted with men and women who held management positions in their organisations. The titles of these positions ranged from director to manager. Interviews followed a semi-structured, in-depth format focusing on four issues:

- Had the organisational structure changed and, if so, how?

- Had any changes been made in the philosophical direction of the agency?

- Had the services provided by the agency changed?

- Had the structure of the workforce changed?

Although a list of general topics to guide the interview was constructed, the intention was to provide the participants with an opportunity to frame their own priorities and speak freely about their agency and changes in its structural organisation. To initiate the dialogue respondents were asked for an overview of what they did in their positions and what services their agency provided to the community.

Often during this first conversation, a great deal of information was gathered pertaining to the general topics on the researchers' list and it was often not necessary to ask direct questions. With the consent of the participants, each interview was tape-recorded and transcribed for analysis. The analysis involved reading and rereading the transcripts with the above issues in mind.

\section{The studied agencies}

In the New Zealand neo-liberal era contracts between government and subcontracting agencies were negotiated with a strong emphasis on accountability. Accountability was measured in the language of outputs and outcomes, and the new arrangements influenced relationships among agencies and between agencies and the state:

Social service organisations, including notable church based not-for-profit entities, found themselves re-cast as 'little arms of the state' and, to a certain extent, forced into competition with each other. (Larner and Craig, 2002, p 18) 
In addition, the contractual requirements often demanded that not-for-profit agencies put in place operational and reporting frameworks that agencies found onerous and costly in both time and financial resources. The managerialism of this era is clearly evident in the profile of the representatives of not-for-profit agencies in Hamilton who participated in this study. The directors and managers interviewed were responsible for as few as 16 to as many as 100 staff members. The titles of those who work in the agencies indicate the managerial focus that has overtaken many such organisations. For example, one interviewee described herself as one of seven in the management team responsible to the general manager. Another was a director responsible for three administration managers and a public relations manager. The director of the smallest organisation reported that she had six office staff, a financial administrator and a funding officer. The director of a medium-sized agency described her role in this way:

'My role is really a dual role. It has got a number of facets but I guess it is primarily seen as a managing role and a directing role and in the manaing role is an expectation that I manage the day-to-day affairs of the agency and give support to the staff. I have oversight of the financial well-being of the agency and $\mathrm{I}$ am responsible for policy development. So that is at a management level, that is what I am expected to do and that takes a lot of time on a daily basis because there are always issues coming up. And on another level I am expected, in the director's role, to be aware of social policy, to be aware of the socioeconomic political kind of environment that we are in, and be able to make sudden strategic responses to that.' (Agency No. 1)

'I always talk about it as like standing on top of a hill and looking out and trying to see beyond the horizon and see where we might be going and given all the factors — social, political, economic — where's the trend taking us and how will we respond to it and, more importantly, how will we be sustainable in the long term.' (Agency No. 1) 
The majority of community welfare agencies in Hamilton are faith-based. An enquiry as to why there is a lack of secular large-scale agencies in Hamilton elicited this response:

'I think now that if you are not seen to have a strong infrastructure that has been around a while, you won't get funded. It's a question of sustainability.' (Agency No. 1)

Although each of the agencies interviewed had a religious background, the agencies were independent of their churches and received funding from various sources. One was not financially supported by its church at all; the others received church funding ranging from $10 \%$ to $30 \%$ of their annual incomes. All of the agencies were dependent on government funding (in contracts to provide services) ranging from $10 \%$ to $45 \%$, grants from Community Trusts, and income from their operations (for example, childcare fees, accommodation rentals and opportunity shops).

Financial information was not available to gauge the size of the organisations but staffing provides an indication. Staff ranged from five full-time and part-time workers with a number of volunteers to 100 full- and part-time staff with no volunteers. In Tampa, US, both organisations had recently undergone managerial changes. Both interviewees had recently been appointed to newly created positions in order to carry out new programmes to cater for the increased numbers of homeless families. Both agencies received funding primarily from the community. Private donations and United Way funds were the main source of funding as well as specific fundraising events held on a regular basis. Both agencies received a small amount of government funding but, at the time of the interviews, the new Bush administration was planning to introduce his faith-based initiatives, which would result in moving more of the social service functions into the private and not-for-profit sectors and would result in increased government monies being allocated to these organisations. As in New Zealand the titles of the interviewees indicate the managerial tone of the organisations. Both the director of the human services department in one agency and the director of programmes in the other were responsible to a governing board of directors:

'First of all our big boss is our board of directors and our president of the board, of course, is the big, big boss. 
They meet, I believe, every other month and we have an Executive Committee that meets monthly and they are the decision-making body, made up of community leaders.' (Agency No. 6)

Both Tampa organisations employed over 100 paid workers and recruited teams of volunteers:

'We have two types of volunteers ... one of them we call them Full-Time Equivalency Volunteers ... they take the place of the staff person and of course it depends on the skill level of the individual. Some of them are counsellors at our office, office receptionists at different desks, maybe teaching classes to clients, you know, wherever their skills are, and the idea is that they will actually take the place of having to hire staff for us.... And then we have our group volunteers. Those are the civic groups, the church organisations, the youth groups, the schools, where they've come as a group usually, sometimes youth, sometimes adults, and they'll do a big project for us.'

(Agency No. 6)

\section{Changes in structure and philosophy}

All of the agencies reported that, over a period of time, changes had been made in the management of their daily activities:

'We changed the structure about, I think, about five years ago. There was a strategic decision made and that was that we couldn't operate in a charity way any more, you know, because the charitable dollar has been so stretched now by different demands.' (Agency No. 2)

'We have a general manager and under that a role of like a senior management team really — set up with myself in the practice consultancy division, we have two operational managers who operate regionally and two practice leaders, which is kind of equivalent to my old role, who operate in conjunction with the operations managers regionally, and then that's supported now by a business manager, by a funding and marketing person.' (Agency No. 2) 


\section{Administering welfare reform}

'There was a deliberate decision made to retrain, so jobs got disestablished but in other jobs like the frameworks of how teams were, it was different, but the agency put a huge amount of money into training, internal training, and we spent two years retraining people.' (Agency No. 2)

Philosophically, Agency No. 2 made what the director referred to as a 'huge change':

'We've moved into a kind of a way of working that we call strength-based practice, which kind of sits outside the traditional ways of working that are more around psychological areas. So that's been a significant paradigm shift really, for us as an organisation.'

Strength-based practice focuses on the competencies, skills and interests of clients in order to find solutions rather than attempting to correct deficiencies. This approach is not only taken by the agency in relation to service delivery, but is also evident in how the agency staff structured organisational change. The staff at this agency are expected to work cooperatively in a team setting. The team incorporates therapists, social workers and community workers, as well as administrative and managerial staff: 'Our belief is that everybody has strengths and abilities ... and we believe that about organisations as well' (Agency No. 2).

The director of Agency No. 2 reported that their change in focus had brought some conflictual issues with other agencies, particularly government services:

'Well, their [the government's] ways of working would be more what we call deficit based. They would be looking for what people were doing wrong and finding ways to fix it. We look at what do people do right and how do you grow it. So it's just a different kind of focus, so that kind of often calls us into conflict with the way that we work, and in lots of instances, because we do the same thing looking from different ways.'

'So we're having to work with people who believe in different things but work with them in a way that is non-adversarial. So there are real challenges in that.' 
Traditionally, faith-based agencies have been funded by their own communities. But as the director of Agency No. 2 reported, the number of church-goers is decreasing:

The people who are still there are aging and that kind of funding resource in a way was dying off. So we had to make some strategic decisions. If we are going to be around, you know, we have to look at an alternative source rather than being able to rely on that kind of funding.'

The new way of working also had ramifications for funding in that the requirements of the funders and the desire for the agency to work in this new way produced tensions for the agency:

'There are challenges for us at a funding level because all the funding structures are set up around contracts that operate in a way that we don't choose to operate. We really need the money so do we go back to operating in the traditional way to fulfil the contract and the reporting requirements or do we work hard to change the way that these funding people think, so that they will fund us for what we do, not what they want?' (Agency No. 2)

The director of Agency No. 1 is passionate about justice and had made it a key focus of the agency:

The shift in philosophy has been to focus and to really underscore that this agency is primarily in pursuit of social justice and we do that through the delivery of social services. So this might be our action, social services is the action, the pursuit through and the philosophical underpinning for the agency is social justice oriented.'

'Justice is not about measurable outcomes, justice is about opportunity, justice is about access, justice is about getting your right to a whole lot of basic life things.'

A year after the interview, Agency No. 1 had changed its name to a short catchy title, and mailed out brochures and produced fridge magnets to promote its new image.

This agency had also dramatically changed its way of working. 
Administering welfare reform

The director discussed extra pressures that were affecting the work staff wanted to do:

'With the devolution of government responsibility back into the community for a lot of the social services, I think that we have picked up more and more of what was formally seen as statutory responsibilities. A lot of our work now comes out of direct referral from government agencies so the whole devolution process by government is a real factor.

We work now in a sort of managerialist model that imposes extra demands upon us in terms of developing commercial systems and working with them keeps us extraordinarily busy because we are under-resourced. It's not just about delivering services, it's about creating systems and structures and maintaining them. Doing all that, who gets any time or energy for activism?' (Agency No. 1)

Agency No. 3 made this comment:

'Compliance has become a major, major issue, you know, and is a major cost. In the time I've been here, this place and many social agencies would be like it, you know, social agencies got on with the job and all they were interested in was the clients, and the workers were only really dealing with that. Over the past, with contracting, you've got this whole business of being responsible and having things that can be audited and so therefore you have to [have] manuals, you have to have processes. All these kinds of things have to be codified.'

In the US, as a result of the Clinton administration initiatives one of the Tampa agencies had made major changes in the way it worked. Two years prior to the interview, the agency, which had traditionally supplied short-term accommodation and residual financial aid, introduced a completely new programme:

'What we found is that our old programme wasn't working any more for people. There wasn't any public housing to put them into any more. There wasn't any 
safety nets of any income that they could get to subside on, and we really had to redesign our programme to give them an opportunity for self-sufficiency without government supports, because that's really the reality of the world these days. So two years ago we redesigned our programme into a self-sufficiency model.' (Agency No. 6)

This programme comprised longer-term family accommodation accompanied by training in order that individuals learn employment, parenting and coping skills together with receiving addiction and violent behaviour counselling:

'The goal is to provide everything that is needed to actually bring a person to self-sufficiency at their own best level, without any government supports.' (Agency No. 6)

\section{Professionalisation}

Traditionally, these not-for-profit social service agencies have been supported by voluntary labour, which has steadily decreased while the call for credentialised workers has increased:

'I recall way back, 15 years ago, when I first agreed to take on this role, that it was sufficient for employees to do the work provided they'd had the experience of their own children. Over the years the onus has been placed on the employees not only to up-skill, to train, but now today they have to be registered. This is the latest enforcement.

There might be the odd volunteer but, no, I think that it is generally accepted that people have a qualification.' (Agency No. 2)

'I think for a whole lot of reasons the volunteer pool that is out there now is still a much older age group. We are talking about people who are 60 plus and 70 plus actually who still work out of the philosophy of the common good.' (Agency No. 1) 
'People now coming in are expected to have professional qualifications. They are expected to have associations with the bodies that they are working under and they are expected to have a sense of professionalism that they didn't formally need to have? (Agency No. 1)

In one agency director's opinion this shift was due to funding requirements, which in turn have resulted in statutory requirements:

'I think it has been because of a funding requirement. I think that, you know, people now say if they are going to fund us they want to be sure that the people who are working in the field are qualified to do it.' (Agency No. 4)

This was echoed by another agency representative who said:

'It's a requirement now for all of our staff to have membership of a professional body. If they don't have it when we hire them, then their training and development plans are geared towards getting it.' (Agency No. 2)

And a third agency:

'Well that's your problem, you see, the moment you have standards, then in a sense you're into the business of having to update qualifications. Now basically from this year on, you've got to have somebody with a diploma and you know that the next step is that somebody will have to have a degree.'

The use of volunteers has become more of a difficulty with agencies because you can only really accommodate certain people within your programmes. Some agencies have programmes where volunteers can do a lot, and if you're giving meals or feeding people, you can use volunteers in those kinds of areas. But the moment you come into a place like us [childcare], we can't use too many. You've got to go through police checks and all that kind of thing, to make sure that they are safe. Anybody that comes to this place goes through police 
checks; we won't have any volunteers or anyone who has not had a police check.' (Agency No. 4)

The Tampa agencies in the US told a similar story:

'I have very few positions that do not require a college diploma in terms of direct provision of services, you know. We have, of course, administrative support positions; we have lower functional positions that while are not unskilled positions do not require that higher level of education ... they require a different group of skills and knowledge.' (Agency No. 7)

\section{The deserving poor}

An additional dimension to the funding issue is the perceived need to specify explicit outputs when agencies are negotiating contracts. These outputs, in turn, become measures of success. In order for funded programmes to generate the specified outcome, they are often targeted at clients who, it is felt, will be `successes'. The result of this model of funding is a new type of deserving poor. Just as in Victorian times when charitable organisations were encouraged to divide the poor into categories of deserving and undeserving, not-for-profit organisations are dividing their clientele. From the beginnings of state support for paupers and the destitute, the distinction between non-disabled people and the defenceless poor has been a moral distinction between the unworthy and worthy - the undeserving and deserving poor.

The notion of deserving and undeserving continues to influence contemporary views on supporting the poor (Cook, 1979; Coughlin, 1980; de Swaan, 1988; Will, 1993; van Oorschot,1998).Van Oorschot (1998) has argued that there is 'deservingness criteria' comprising control, need, identity, attitude and reciprocity. Van Oorschot referred to control as the control that poor people have over their own neediness. The deserving poor are those whose situation is beyond their control; the undeserving are those 'who could make a living on their own, if they only tried or tried hard enough' (van Oorschot, 1998, p 3). Will's (1993) study on who the public perceives as the deserving poor in America found that the highest level of support was for large families, unemployed people and physically disabled people, and particularly for those who actively strived to help themselves. 
The deserving are also distinguished from the undeserving poor on the basis of level of need - the greater the need, the more deserving people are. Cook (1979) found that, generally, willingness of others to help was based on the level of neediness. Thus there was more willingness to support those who were in greater need of help.

The moral identity of the poor is based on their 'location' relative to 'in-group favourability' (Messe et al, 1986). Deservingness is based on the degree to which the poor belong to 'Us' (van Oorschot, 1998, p 3). The 'Us' may be identifiable groups such as family, town and church, and 'in modern, national societies this criterion might result in an unwillingness to support needy people from ethnic minorities or foreign residents in general' (van Oorschot, 1998, p 3).

The attitude criterion refers to the attitude of those in need. De Swaan's (1988) 'docility' and Cook's (1979) 'gratefulness criterion' describes the level to which poor people acknowledge the help they are given: 'the gratefulness criterion holds that the inclination to support is higher towards those people in need who respond gratefully for help' (van Oorschot, 1998, p 3).

The criterion of reciprocity is an extension of attitude. The idea of reciprocity in social relations - giving and taking — is the basis of this criterion. While the poor may have little to reciprocate with at the time except for their compliance or gratefulness, they may have previously earned support. The almost universal acceptance that older people who have already contributed to society are deserving of help is a clear example of this notion of reciprocity.

\section{The deserving and undeserving poor in New Zealand}

Referring to the concept of the deserving and undeserving poor in New Zealand in the 1990s, Cheyne et al (2005, p 21) argue that:

Nineteenth-century debates of laissez-faire and charitable aid have a similarity to the rhetoric that underpins the retrenched welfare state of the 1990s. There is a common stress on self-help and non-interference in the marketplace.

The New Zealand government's funding criteria for welfare agencies and the need for successful outcomes reflect this continuing dichotomy of deserving and undeserving poor. In order to access 
funding, agencies are obliged to show 'success' in what they do. But the agencies face the issue of what is meant by 'success':

'I mean, how do you measure success? That's the thing that has been difficult for us because generally contracts have been measured by how many people you put through, you know, that's the traditional way. You know, you get three sessions and then you're out and next person is in. But we know that's not successful, and so we work with our own measures of success knowing that they're not going to be fully funded, because they're still being funded on the basis of output not outcome.' (Agency No. 2)

'The resources are limited, I mean we can't keep on pouring money in, in ways that, you know, that haven't been well thought out, haven't been targeted, haven't been coordinated. We've noticed that for the government funding that we do have, reporting for that used to be a matter of filling in a form, you know, they give you the money at the end of the year and you fill in a form. Well now we have stringent audits, they come along and they want to not just look at how you spent the money, they want to look at your professional practice and how you know that you've been successful and what kind of internal support systems you have. I think the government is demanding a lot more for their money now.' (Agency No. 2)

One of the things that seems to be coming through is that this whole evaluation area, you know, proving that you actually do people some good and measuring that is difficult really.' (Agency No. 5)

'What is success in addiction programmes? Drying the guy but? Is that success? Getting their health back, because often they've sluiced all the vitamins out of their system and that kind of thing and so therefore you restore their health and you might get them back to a state of sobriety, is that success? Or do they need to do one week's sobriety or do they need to do three months, or do they need to do six months, or 12 months? You know, 
what is success with addiction? And with counselling, what is success?' (Agency No. 5)

Despite the dilemma of defining what success means, agencies have changed their way of working in order to meet these criteria by targeting their clientele:

'A lot of it is about funding. If you can demonstrate that you have a specialist way of working and that you will target a particular group. And so that is what is tending to happen. We are getting a lot of specialist agencies now who are saying that they work from specialist models and target a particular group in the community and you could say that's part of the "deserving poor" model. That's a funding requirement that still comes out of that whole 15 years of producing results. We were told we would get so much money and we had to demonstrate that three months down the track this family was cured or that there were good outcomes for this family. Significant outcomes, not just minor outcomes. And so with the funding, as with professionalisation, it starts to get targeted.' (Agency No. 1)

'The reality is a lot of people access our [counselling] services because it's affordable. It's based on donation and ability to pay. Generally the people who come can't afford to pay and the income they're getting is really low, and there's a real debate even internally in the agency because you're constantly pressured into prioritising people who can come attached with funding. So that there's always the pull for us if we want the contract. Does that mean that we can only take people who are bad enough to fit the criteria?' (Agency No. 3)

\section{The deserving poor in Tampa}

When asked about the notion of the deserving poor, the interviewees in Tampa, US, both acknowledged that the public at large perceived people as deserving and undeserving but did not connect that notion to the programmes in their agencies. The director of the agency that had introduced the completely new programme said: 'I'd say usually the wealthy business-type successful 
professionals are the ones that are most likely to want to help the deserving and not the undeserving'.

While the director of the second agency said of the first:

'We have another major provider here in the area who last year, unannounced, closed their emergency shelter so that they were no longer going to be providing services to street people because to provide emergency shelter services was just enabling them to remain where they were. If they wanted to make the choice to enter a transitional programme and to do the things they needed to do to get their lives on track then they could come into their programme. So I guess that would be consistent with that of providing services for the deserving poor.' (Agency No. 7)

This first agency had an ethos of self-help in order for its programme to be judged successful:

'Basically they can come and stay with us when they're ready to make a change in their life. We can't let them propagate what they've been doing if it's been drinking, if it's been drugging, if it's them refusing to work or whatever, but once they get to a point in their life where they say "Okay, I'm ready to make a change", that's when they are most appropriate for our programme.' (Agency No. 6)

The director of the second agency acknowledged the connection between funding and success:

'Perhaps some services should be restricted to individuals that are ready to change and I think that we have an ethical responsibility to utilise resources where they are going to be the most productive. I mean, you know, the people that are providing our resources have that in mind when they give it. They want to help people to improve their situation.' (Agency No. 7) 


\section{Conclusions}

This chapter has examined non-governmental agencies in two cities, one in New Zealand and one in the US, which have taken up the growing residual welfare that comes out of a neo-liberal idea of less government and more individual responsibility on the part of their populations. Over the past 15 years the argument that the economic difficulties faced by industrial countries have been caused by welfare systems using resources that could otherwise be invested in industry has gained momentum. Political parties of both the left and the right have advocated a neo-liberal reliance on market forces and subsequently limited welfare spending to programmes that are cost-effective, targeted and which can demonstrate quantifiable outcomes.

The change in governance in New Zealand to a deregulated, market-led state that relied on community welfare resulted in a non-governmental sector struggling to cope with a burgeoning responsibility exacerbated by a demand (by government funders) for fiscal responsibility and proof of measurable success. In order to cope with those demands, agencies were forced to mirror the private sector by restructuring their management systems and seeking to make a 'profit' by ensuring that their services and programmes were not wasted on the 'undeserving'. In the US, changes in one agency's way of working due to the Clinton administration initiatives resulted in similar outcomes. Although the character of the reforms were not as potent as those in New Zealand, the need to create programmes that accomplished more than merely housing and feeding people as a temporary measure, meant that those who were targeted for the programme were those who were committed to changing their personal behaviour and thus become deserving of welfare.

As we progress through the first decade of the 21st century, the non-governmental sector continues to encounter greater demands on its time, resources and energy. The ideology of individualism, personal responsibility and welfare-generated dependency creates an atmosphere very much like that dominant in the late 18th century. Economic rewards are governed by the operation of the free market and 'every man [sic] should be free to pursue his fortune and should take responsibility for its success or failure' (Conley, 1982, p 282). 


\section{References}

Acker, J., Morgen, S. and Gonzales, L. (2002) Welfare restructuring, work and poverty, Eugene, OR: Center for the Study of Women in Society, University of Oregon.

Cheyne, C., O'Brien, M. and Belgrave, M. (2005) Social policy in Aotearoa New Zealand: A critical introduction (2nd edn), South Melbourne: Oxford University Press.

Conley, M. (1982) 'The "undeserving" poor: welfare and labour policy', in R. Kennedy (ed) Australian welfare history: Critical essays, South Melbourne: Macmillan, pp 281-303.

Cook, E (1979) Who should be helped: Public support for social services, Beverly Hills, CA: Sage Publications.

Coughlin, R.M. (1980) Ideology, public opinion and welfare policy: Attitudes towards taxes and spending in industrial societies, Institute of International Studies, Research Series No. 42, Berkeley, CA: University of California.

De Swaan, A. (1988) In care of the state, Amsterdam: Bakker. Deacon,

A. (2002) Perspectives on welfare, Buckingham: Open University Press.

Gray, J. (1998) False dawn: The delusions of global capitalism, London: Granta Publications.

Hartford Institute for Religion Research (2000) How do people perceive religious meaning in faith-based social services? Congregations, Communities and Leadership Development Project (online), available at: http://hirr.hartsem.edu/research/ research_churchoutreach_perceptions.html

Kelsey, J. (1995) Economic fundamentalism, London and East Haven, CT: Pluto Press.

Larner, W. and Craig, D. (2002) After neoliberalism? Local partnerships and social governance in Aotearoa/New Zealand, Research Paper No. 3, Auckland: University of Auckland.

Messe, L., Hynmes, R. and MacCoun, R. (1986) 'Group categorization and distributive justice decisions', in H.W. Bierhoff, R. Cohen and J. Greenberg (eds) Justice in social relations, New York and London: Plenum Press.

Ministry of Social Development (MSD) (2005) Leading social development, Ministry of Social Development Statement of Intent 2005/6, Wellington: Ministry of Social Development.

PRWORA (Personal Responsibility and Work Opportunity Reconciliation Act) (1996) Washington, www.acf.dhhs.gov/ programs/ofa/prwora96.htm 
St John, S. (1994) 'The state and welfare', in A. Sharp (ed) Leap into the dark: The changing role of the state in New Zealand since 1984, Auckland: Auckland University Press, pp 89-106.

US Department of Health and Human Services (1996) Administration for children and families, Fact Sheet, 22 August.

van Oorschot, W. (1998) 'Who should get what, and why? On deservingness criteria and selectivism vs universalism among the Dutch public', paper presented at the 2nd International Research Conference on Social Security of the International Social Security Association (ISSA), Jerusalem, 25-28 January.

Weaver, K. (2000) Ending welfare as we know it, Washington, DC:

Brookings Institute.

Will, J. (1993) 'The dimensions of poverty: public perceptions of the deserving poor', Social Science Research, vol 22, pp 312-32. 